\title{
DOES EL NIÑO AFFECT BUSINESS CYCLES?
}

\author{
Thanarak Laosuthi \\ University of Kentucky
}

and

\section{David D. Selover \\ Old Dominion University}

Most people think of El Niño as a slight warming of ocean temperatures in the Pacific accompanied by storms, heavy precipitation, and unusual weather patterns. ${ }^{1}$ But El Niño is much more than that. The El Niño-Southern Oscillation (or ENSO) has been held partially responsible for some of the world's greatest humanitarian disasters. Davis [2001] documents the global El Niño droughts of 1876-78, 1888-91, and 1896-1902, and graphically describes how the droughts contributed to the deaths of millions of people in India, China, and Brazil. ${ }^{2}$ The potential economic implications for such global climatic fluctuations are enormous, and historically, the effects of El Niño have at times been very large. This makes knowledge of El Niño conditions all the more important in making economic policy.

In this paper we examine the effects of the El Niño phenomenon upon twenty-two economies and their business cycles. The main question is, what effect does the El Niño-Southern Oscillation have upon the macroeconomies of the world? Reminiscent of William Stanley Jevons' [1884] nineteenth century sunspot theory of business cycles, this phenomenon, is tested for its effects on national business cycles. To that end we study the effects of the El Niño-Southern Oscillation upon GDP growth, consumer price inflation, and commodity price inflation in various countries. Using the Southern Oscillation Index (SOI) as a measure of the magnitude of El Niño events, we use graphs, correlations, and Granger causality tests to examine and test for the effect of the El Niño-Southern Oscillation upon the business cycles of various countries, especially the smaller, lesser developed countries directly in the regions most affected by the ENSO phenomenon. If the effects are large, then the El Niño should be taken into consideration in the formulation of macroeconomic policy.

Several researchers have examined the microeconomic effects of El Niño, but only one, Brunner [2002], has looked at the macroeconomic effects. Brunner [2002] has estimated that the ENSO is responsible for about $10-20$ percent of the variance in world GDP growth and world consumer price inflation and about 20 percent variation in real commodity price inflation over the 1963-1997 time period. Our research differs from that of Brunner in emphasis, methodology, and results. While Brunner

David D. Selover: Department of Economics, Old Dominion University, Norfolk, Virginia 23529. E-mail: dselover@odu.edu. 
mainly focuses on commodity prices, we focus on the effects of El Niño on economic growth and inflation, in addition to commodity prices. While Brunner examines an aggregate of the growth and inflation rates of the developed G-7 nations, we study the El Niño effects on individual countries, especially upon the developing countries most susceptible to the phenomenon.

We discover the El Niño effects to be much weaker than those found by Brunner. Our main finding is that El Niño has relatively little detectable effect on the business cycles of most of the countries that we study. The El Niño appears to significantly affect mainly South Africa, Australia, India, and perhaps Malaysia. Most of the graphs show relatively little synchronization between the El Niño SOI index and the real GDP growth rates and consumer price inflation rates of the different countries. The correlations and Granger causality tests from ENSO to economic growth and inflation are largely insignificant. In view of the enormous potential size of the ENSO effects, these findings are somewhat surprising.

On the other hand, perhaps we should not be surprised. The El Niño acts to redistribute heat and precipitation. It bestows beneficial effects on economies as well as negative effects. To a certain extent, these positive and negative effects cancel each other out. The cancellation effect is likely to be more complete, the larger the geographical area of a country and/or the more diversified the economy. One researcher, Changnon [1999], has estimated that the costs of the relatively large 1997-98 El Niño upon the United States amounted to about $\$ 4$ billion. However, this was more than offset by about $\$ 19$ billion in benefits, for a net benefit of $\$ 15$ billion. It is noteworthy that while these benefit and cost amounts are large, they were small relative to the $\$ 8.5$ trillion size of the US economy in 1997-98, amounting to less than 0.2 percent of GDP. These estimates also illustrate the fact that El Niño can bestow benefits as well as exact losses, and that for large countries, the benefits and costs may tend to cancel each other out.

This research has policy implications because if El Niño has significant economic effects and if meteorologists are able to accurately forecast the onset of an El Niño or La Niña event, then farmers, fishermen, disaster preparedness personnel, financial markets, central banks and governments will be able to take protective and adjustment measures before the event begins. Microeconomic and macroeconomic policies could be adjusted correspondingly. However, we find that macroeconomic adjustments do not appear to be necessary for most countries.

The next section provides some background on El Niño, and the next reviews the economic literature. The section after that presents a rudimentary theoretical model of the economic effects of El Niño upon national economies. The next section describes the data and the econometric analysis, followed by a section that presents the empirical results of the analysis, and a final section which concludes.

\section{BACKGROUND}

The El Niño-Southern Oscillation (ENSO) is a global atmospheric-oceanic phenomenon in which the atmosphere and ocean interact to form an oscillatory system which affects air temperatures, air pressures, wind patterns, humidity levels, 
precipitation patterns, weather patterns, storm tracks, ocean water temperatures, thermocline depths, ocean currents, ocean nutrient patterns, and marine life in the Pacific Ocean. This oscillating system produces irregular cyclical fluctuations in all of the above variables.

The pervasiveness of the ENSO phenomenon has come to the attention of the scientific community only relatively recently. The El Niño-Southern Oscillation accounts for a number of heretofore unexplained fluctuations in weather patterns around the world. It is increasingly being realized that the El Niño phenomenon provides much of the explanation behind the periodic long periods of drought, unusual precipitation, flooding, unusually higher or lower temperatures, and unusual storm paths of hurricanes and tornados in different parts of the world. Moreover, there are several other such systems of "oscillations" around the globe, including the North Atlantic Oscillation, the North Pacific Oscillation, the Bermuda High, and others. Being associated with the largest ocean, the Pacific, the El Niño-Southern Oscillation appears to be the dominant such system. These systems appear to be loosely linked via "teleconnections," thus allowing El Niño's effects to be felt in distant parts of the world, such as in Africa and India.

FIGURE 1

Southern Oscillation Index 1950 - 2001

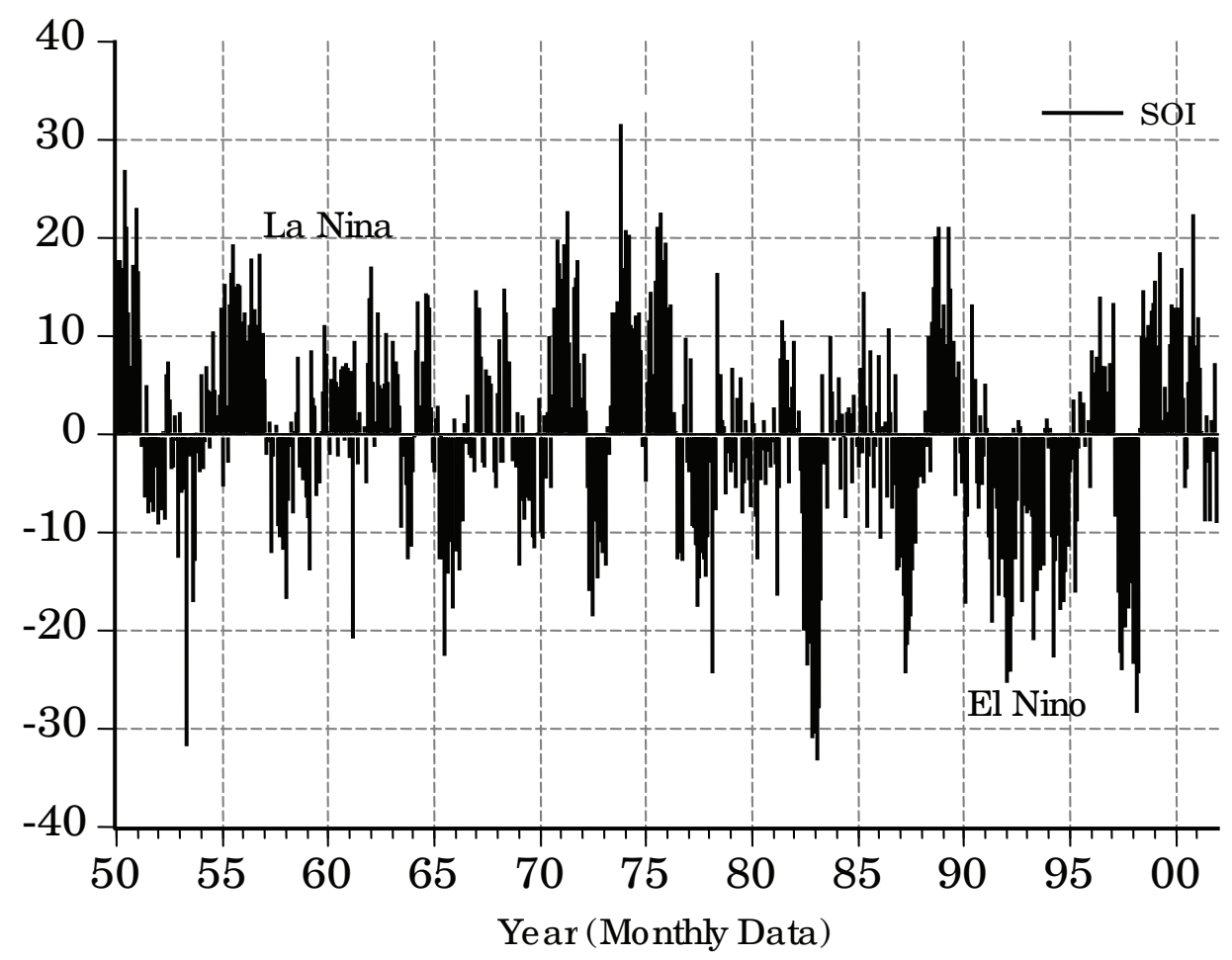


The El Niño-Southern Oscillation phenomenon is in certain aspects similar to business cycles, with irregular fluctuations varying from $3-7$ years in length, see Figure 1. One side of the ENSO cycle, the warm phase, is called the "El Niño" and lasts about 12-18 months in length. The other side, the cold phase, is called "La Niña" and lasts a similar length of time. In this research we ask whether or not the ENSO climatic phenomenon has an effect on business cycles and commodity prices around the world.

In an El Niño event, humid regions tend to dry out and experience drought, while desert regions receive large amounts of rain and become subject to flooding. Tropical storms and hurricanes are diverted from their usual paths and hit regions unaccustomed to their occurrence. El Niño can therefore have dramatic effects on storm incidence, hurricanes, flooding, droughts, forest fires, and smog formation. These changes in weather patterns can have a potentially large impact on the economy because they can have critical effects on agriculture, fishing, and construction. La Niña, on the other hand, is just the other side of the same ENSO phenomenon, and its effects are just the opposite of those of El Niño. For example, while El Niño brings rains to the west coast of South America, La Niña brings drought.

Because of the enormity of the ENSO effect and its subtle linkages with other climatic oscillations around the world, ENSO displays effects reaching far beyond the realm of the Pacific Ocean region. A modest warming of the equatorial Pacific waters by $1^{\circ}-2^{\circ} \mathrm{C}$ during an El Niño event can have dramatic effects upon climates thousands of miles away. For the United States, an El Niño event typically means heavier rains and flooding in California, generally warmer winters in the Northeast, increased rainfall in the South, diminished tornadic activity in the Midwest ${ }^{3}$, and a decrease in the number of hurricanes to hit the East coast.

For South America, the El Niño brings drought to Venezuela and northeastern Brazil, an increase in forest fires in the Brazilian rainforest, but increased rainfall in Southern Brazil, Uruguay, and Argentina. The very arid west coasts of Peru and Chile experience dramatically increased amounts of rainfall, leading to flooding, and in the spring, remarkable amounts of vegetation and abundant crops. For this reason, the years in which El Niño occurs were traditionally known in Peru as "años de abundancia," - years of abundance. However, the El Niño is better known for greatly reduced fish catches off the west coast of South America, due to the warmer waters, a decreased ocean upwelling, and a decrease of surface nutrients in the water to support sea life.

For the western Pacific, including Australia, Indonesia, Southeast Asia, the Philippines, Oceania, Fiji, and Micronesia, an El Niño event brings drought. The usually abundant rainfall shifts eastward away from Southeast Asia and Australia toward South America. This results in a lack of rainfall, drought, a loss of crops, uncontrolled forest fires, and sometimes creates a huge smog problem over the Southeast AsianAustralian region. A persistent El Niño related heavy smog occurred in Southeast Asia in 1997, a consequence of drought and forest fires in Indonesia.

For China, an El Niño event results in a dry year and fewer typhoons for northern China. Conversely, the El Niño brings heavy rains and flooding to southern China, in essence inverting the precipitation patterns between north and south. For India 
and Pakistan, ENSO events tend to suppress the summer monsoons, thus bringing drought to the subcontinent. The El Niño is also correlated with drought in southern and eastern Africa. From this list of climatic effects it is clear that the El Niño phenomenon has global consequences. A La Niña event is associated with a reversal of the above results.

\section{LITERATURE REVIEW}

Much has been written in the meteorological and oceanographic literatures about El Niño and its effects on agriculture and fisheries, and on storm activity. Most of this literature is microeconomic in approach. Costello, Adams, and Polasky [1998] found that the variability in the fisheries, especially in the salmon stocks of the US Pacific northwest, depends on variability in the climate. Dalton [2001] finds that El Niño has positive effects on the abundance of albacore and negative effects on Chinook and squid in Monterey Bay. Jordan [1991] found that the fishing industry output along the west coast of South America did indeed decline during El Niño years.

Legler, Bryant, and O'Brien [1998] attempted to estimate the impact of ENSO climate anomalies upon US crop yields over the period 1948-1987. Using a simulation model they studied seven crops: barley, cotton, corn, rice, sorghum, soybeans, and wheat. The crop yield effects are dependent upon an interaction of temperature, precipitation, weather variability, location, and timing. They noted that the impacts depend largely on the region and on the crop, with some regions and some crops being harmed and others enhanced. Handler and Handler [1983], Letson and McCullough [2001], and Roll [1984] also find correlations between the ENSO phenomenon and crop production and prices.

Kreitner, Smith, and O'Brien [2000] found a significant increase in extreme storms and flash flood frequency in Colorado and South Dakota during the onset summer of an ENSO warm phase over the last decade. On the other hand, Knowles and Pielke [1993] and Bove [1999] found reduced tornado activity in the southern plain states during an El Niño event, while a La Niña event is correlated with large tornado outbreaks and more devastating tornadoes. Gray [1984] and Richards and O'Brien [1996] found that El Niño events were associated with reduced hurricane activity in the United States. Bove et al [1998] found that the probability of two or more hurricanes making landfall in the United States dropped from a normal 48 percent to a low 28 percent during an El Niño event. Conversely, that probability rose to 66 percent during a La Niña event.

Bidegain and Krecl [1999], Ropelewski and Halpert [1987; 1989], and Grimm et al [1998] studied the impact of El Niño on the temperature and rainfall in South America and found that ENSO brought above average rainfall to southern Brazil, Uruguay, and eastern Argentina.

Adams et al [1995] estimated the value of improved ENSO forecasts in the Southeastern United States. They found that a perfect forecast of ENSO events is worth $\$ 145$ million. These potential savings (from a perfect forecast of ENSO events) are relatively small relative to the size of the US economy (about .0021 percent of GDP or less). 
Keppenne [1995] employed multichannel singular spectral analysis, a time series form of principal component analysis, to examine the relationship between El Niño and soybean futures prices. He found a statistically significant ENSO signal in soybean futures prices, suggesting that El Niño had an impact on the production of soybeans. He also found that wheat and corn futures prices did not respond significantly to the ENSO variable.

Most of these studies are microeconomic in nature, focusing on individual markets. However, relatively little has been written about the effects of El Niño in the economics literature, and even less has been written about the macroeconomic effects of $\mathrm{El}$ Niño. Probably the most comprehensive study until now of the macroeconomic effects of El Niño is Brunner [2002], which attempts to quantify the worldwide impacts of El Niño upon GDP growth, consumer prices, and commodity prices for an aggregate of countries. Using quarterly data over the period 1963-1998, Brunner uses graphs, Granger causality tests, vector autoregressions (VARs), and impulse response functions to test the effects of El Niño upon an aggregate of world commodity prices, aggregated G-7 consumer price inflation, and GDP growth. He finds that El Niño has "economically important and statistically significant" effects upon world commodity prices and that it accounts for almost 20 percent of the movements in world real commodity price inflation over the period. He also finds that El Niño accounts for about 10-20 percent of the movements in the aggregate G-7 consumer price inflation and aggregate G-7 GNP growth.

A weakness of the Brunner paper is that, instead of looking at the El Niño effects on individual economies, it aggregates the relatively large and diversified G-7 economies together, and tests this aggregate of G-7 economic growth for an El Niño effect. Using an aggregation of economies does not appear to be a reasonable approach because aggregation would increase the probability of a cancellation of positive and negative El Niño effects that might appear. It is more likely that one would find El Niño effects if one analyzed smaller, less aggregated, and less diversified economies, especially those economies in the actual El Niño regions of the Pacific Basin, instead of the G-7 economies. It would seem more probable that the El Niño would display larger effects on the more heavily agriculture or fishing oriented economies in the Pacific region, like the economies of Central America, the west coast of South America, Australia, Oceania, and Southeast Asia.

The present paper generally follows Brunner's research strategy, except that we test the various countries and commodity prices individually instead of in the aggregate, we use Granger causality tests instead of impulse response analysis, and we study developing countries, which would seem to be more susceptible to the influence of the El Niño. We expect the ENSO to have a greater influence upon the smaller, less diversified economies, coastal economies, heavily agricultural economies, and maritime economies, especially in the Pacific.

In a finding somewhat contrary to that of Brunner, Norrbin and Schlagenhauf [1988], examining the sources of macroeconomic fluctuations in the United States, found that weather variables are insignificant at explaining regional fluctuations in the US. 


\section{THE ECONOMIC MODEL}

An El Niño event can have effects on economies primarily via its effects on temperature, precipitation, and storms upon fisheries and agriculture, and also its effects on heating, cooling, and snow removal. Additionally the effects of increases in flooding, mudslides, hurricanes, and tornados may be sizeable.

According to portfolio theory, the El Niño effect should be relatively strong for small and/or less diversified developing countries. Conversely, the El Niño effects should have a diminished impact on geographically large or well-diversified economies. It should have even less effect upon an aggregation of countries or commodities because of the consequences of diversification and the cancellation of positive and negative effects. The bottom line is that larger countries and more diversified countries should be relatively less affected by ENSO fluctuations than smaller, less diversified countries, everything else held equal. The ceteris paribus assumption is necessary because it is always possible for a vulnerable large country to be more strongly affected than a smaller country if it has characteristics more vulnerable to El Niño effects. A good example is India, which is very dependent upon the seasonal monsoons for agriculture.

This theoretical diversification result is supported by Changnon's [1999] empirical findings for the US, in which different regions are affected differently by El Niño, leading to a cancellation effect. Such finds are also reflected by the history of El Niño effects in China and Brazil where in both countries the northern and southern regions are affected in opposite ways. During an El Niño the northern regions of both countries experience drought while the southern regions experience heavier than normal rainfall, and during a La Niña the effects are reversed.

Needless to say, this simple asset diversification model oversimplifies the El Niño effect and ignores other issues of the phenomenon. For example, we use a univariate measure (the SOI index) to gauge the strength of the ENSO, when in fact the phenomenon is multidimensional. The El Niño phenomenon displays random patterns in the distribution of its effects, and the geographical distribution of temperatures and atmospheric pressures of El Niño may differ from episode to episode. The effects of El Niño may be largely felt in Peru during one episode, and perhaps more strongly felt in Central America in the next episode. Therefore our measure of the El Niño effects is imperfect because it neglects the geographic dimensions and variability of the phenomenon. Consequently different El Niño events of equal SOI intensity may look quite distinct when plotted on a weather map, and may have markedly different economic effects on a given region from event to event.

Additionally, although the occurrence of an El Niño may affect the incidence or probabilities of storms or hurricanes, it does not guarantee that the storms will occur. For that reason, sometimes the El Niño may be accompanied by storms, and sometimes it may not. This randomness will further weaken the correlation between El Niño and economic growth.

These factors would tend to weaken the correlation between the ENSO phenomenon and the annual weather, and hence weaken the correlations between the SOI and macroeconomic performance. 


\section{THE METHOD OF ANALYSIS AND THE DATA}

Our sample includes countries selected on the basis of their proximity and vulnerability to the ENSO effects. We also examine a number of larger, advanced countries, less likely to be affected. The developing nations in the sample include Brazil, Chile, Colombia, Costa Rica, Ecuador, El Salvador, India, Indonesia, Malaysia, Mexico, Peru, Philippines, South Africa, and Thailand, while the more developed countries include Australia, Canada, France, Germany, Italy, Japan, the United Kingdom, and the United States. Since a relatively long time series is required in order to include a number of El Niño cycles, we should pay more attention to the annual data rather than the more numerous quarterly or monthly data. ${ }^{4}$

The most common and important index used to measure the strength of the ENSO phenomenon is the Southern Oscillation Index (SOI). The Southern Oscillation Index is based on monthly deviations from the monthly mean in the air pressure differential between Tahiti and Darwin, Australia. ${ }^{5}$ The SOI usually ranges between -35 to +35 , with large negative numbers indicating an El Niño event and large positive numbers indicating a La Niña condition. The SOI is usually calculated on a monthly or annual basis, because daily or weekly values are not very useful for measuring ENSO effects, due to the daily fluctuations in weather and air pressure.

Figure 1 displays the monthly SOI over the period 1950 - 2001. Remembering that negative values indicate the presence of an El Niño, note that the El Niño events of 1982-1983 and 1997-1998 were among the strongest of the century.

The object of the investigation is to analyze the data for any correspondence or correlation between the business cycles of the sample countries and the El Niño-Southern Oscillation fluctuations. For the business cycle variables we use the real GDP growth rates and inflation rates for each sample country. We use individual commodity price inflation rates to study the effect of El Niño events on commodity prices. As a measure of the strength of El Niño episodes we use the monthly Southern Oscillation Index (SOI) for the month, averaged for the quarter, and averaged for the calendar year, depending upon the analysis. ${ }^{6}$ For the analysis we examine graphic evidence, correlations, and tests of Granger causality. ${ }^{7}$ In order to perform valid tests and to prevent the finding of spurious correlations, we first tested the variables for non-stationarity using an Augmented Dickey-Fuller (ADF) test, see Engle and Granger [1991]. ${ }^{8}$

While most of the national GDPs (in logs), CPI prices (in logs), and commodity prices (in logs) were found to be I(1) nonstationary, the El Niño indicator, the Southern Oscillation Index (SOI), was found to be $\mathrm{I}(0)$ stationary. Consequently there was no possibility of meaningful cointegration between the El Niño index and the logs of national GDPs and prices. ${ }^{9}$ For that reason, the logs of the nonstationary GDP and price variables were differenced in order to achieve stationarity, and the subsequent analysis were done with the $\log$ differenced data, $y_{t}$, i.e., growth rates and inflation rates.

For the Granger causality tests we estimated equations of the following form:

$$
\Delta \ln y_{t}=\alpha+\sum_{i=1}^{p} \beta_{i} \Delta \ln y_{t-i}+\sum_{i=0}^{p} \gamma_{i} S O I_{t-i}+\varepsilon_{t}
$$


The usual Granger causality test relies on the "arrow of time" to distinguish the direction of causality by using only lags of the explanatory variable being tested. However, here the ENSO explanatory variable (SOI) is clearly exogenous. For that reason we can include a contemporaneous term (with no lag) which allows us to test for the contemporaneous effects of El Niño. ${ }^{10}$ The modified Granger causality test is then a joint hypothesis test on the $\gamma_{i}$ coefficients using an F-statistic. With this test we are testing the significance of the SOI (the Southern Oscillation Index) in explaining the $\Delta \ln y_{t}$ variable. The use of the lagged $\Delta \ln y_{t-1}$ 's is a proxy for the effects of other explanatory variables. As always, the Granger causality test is subject to the criticism that it omits other crucial explanatory variables and that therefore the results are subject to omitted variables bias. For that reason we have also redone the Granger tests using other exogenous variables such as oil price inflation or, in the case of Chile, copper price inflation. The results from these tests do not change the results from those reported here. ${ }^{11}$

\section{THE EMPIRICAL RESULTS}

Graphs, correlations, and tests of Granger causality were used to study the relationship between El Niño and economic activity. In general the ENSO (represented by the SOI index) displayed surprisingly few significant negative or positive effects upon the business cycles of the countries studied. These neutral results may be partially explained by the fact that the El Niño phenomenon has both positive and negative effects upon economies, and these effects may tend to cancel each other out. This is especially true for economies which are geographically large, as Changnon [1999] found for the US.

In addition to this cancellation effect, for large diversified economies like the United States, only a small percentage of the economy is accounted for by the agriculture and fishery sectors. Less than 2.0 percent of US GDP is in agriculture, and fisheries account for an even smaller part of the economy. Consequently, even a large negative shock to a major agricultural region in the US (highly unlikely) would not seriously affect the overall economy. World trade would tend to ameliorate the effects of any large agricultural crop failures. Moreover, the effects of El Niño may be positive or negative depending upon the crop in question.

The effects of El Niño are more likely to be more significant for smaller, less diversified economies, dependent on single-crop agriculture or fisheries. Consider the percentage of national GDP in production in agriculture, hunting, forestry, and fishing of various countries. The amount of agriculture, hunting, forestry, and fishing as a percentage of GDP in Latin America is relatively high (from 5.2 percent to 13.0 percent), and the percentages for the south and southeast Asian countries are even higher (from 11.3 percent to 29.3 percent), making their economies more vulnerable to climatic fluctuations. India, with a very high proportion of the economy (almost 30 percent) involved in agriculture, may be especially vulnerable. In contrast, the more developed countries have dramatically lower percentages of GDP devoted to agriculture, hunting, forestry, and fishing (1.2 percent to 4.0 percent), and are therefore likely to be less vulnerable to fluctuations in weather and climate. 


\section{Correlations and causality tests between SOI and GDP growth}

Figure 2 shows the graphs of the GDP growth rates of various selected nations in comparison with the SOI index. If El Niño were responsible for part of the national business cycle, one might expect to see a certain amount of correspondence between the two. However, in these examples it is difficult to discern any real degree of correspondence between the SOI and the growth rate of the countries studied, except perhaps for South Africa and Australia, and for certain events, India.

FIGURE 2

GDP Growth and the SOI Index
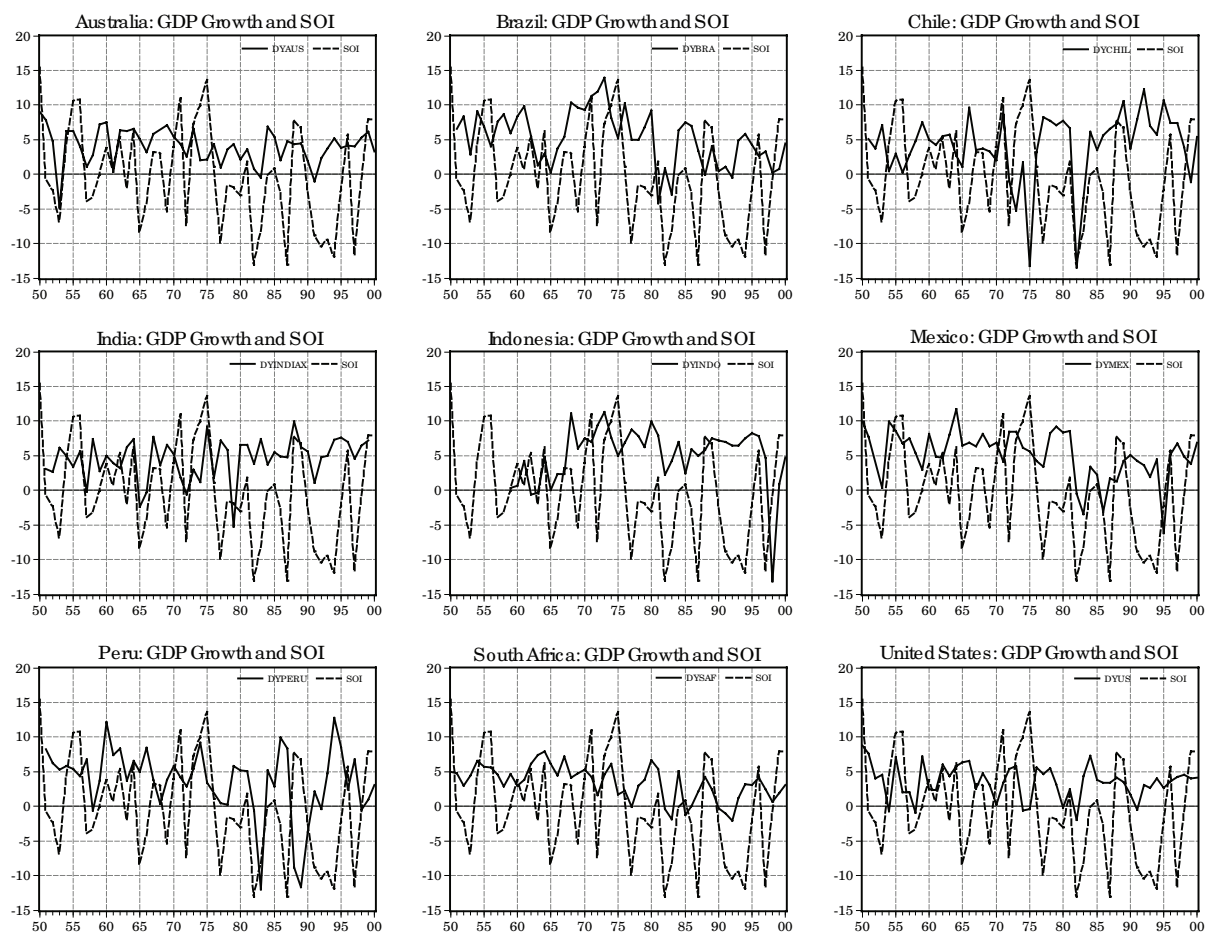

Table 1 reports the correlations and tests of Granger causality between the El Niño Southern Oscillation Index (SOI) and the annual GDP growth of some twentytwo nations. In particular we are most interested in robust results for a country in which there is repeated evidence of statistical significance for various lag lengths and frequencies. The data is annual, spanning from 1951 to 2000 for most countries. A negative value of the SOI index indicates the occurrence of an El Niño event. If the El Niño event has a negative effect upon an economy (as one might expect) ${ }^{12}$, one would expect to observe a positive correlation between the SOI index and GDP growth. In this table sixteen out of twenty-two countries display a positive correlation between GDP growth and the SOI index. However, only five of the countries have correlation 
coefficients with SOI that are statistically significant. Testing the proposition that the ENSO (SOI) Granger causes GDP growth, columns three through four display the results of Granger causality tests with a contemporaneous term and one annual lag, and columns five through six display the results of Granger causality tests with a contemporaneous term and two annual lags. It is unlikely that an El Niño event would take longer than two years to have an impact on the economy. South Africa and Australia, and perhaps India and Mexico, are statistically significantly influenced by El Niño. None of the other countries show statistically significant evidence that the El Niño-Southern Oscillation Granger causes national GDP growth. India is perhaps a special case because the timing of the vital annual monsoon rains depends to a large extent upon effects from the Southern oscillation and because of India's reliance on agriculture. Interestingly, it is the research into the monsoon variability in India that led to the original discovery of the Southern Oscillation in 1924. When oil price shocks were added to the Granger causality test specification, the results were largely unchanged.

TABLE 1

\section{Correlations of National GDP Growth with El Niño SOI and} Tests of Granger Causality: SOI $\rightarrow$ Growth (Annual Data: 1950 - 2000, some series shorter)

(Each test includes a contemporaneous term plus a number of lags of SOI.)

\begin{tabular}{|c|c|c|c|c|c|}
\hline & $\begin{array}{c}\text { Effects on GDP } \\
\text { Growth }\end{array}$ & & & & \\
\hline Country & $\begin{array}{l}\text { Correlation with } \\
\text { SOI (p-values) }\end{array}$ & $\begin{array}{c}\text { Granger } \\
\text { Causality } \\
\text { (1 lag) }\end{array}$ & P-Value & $\begin{array}{c}\text { Granger } \\
\text { Causality } \\
\text { (2 lags) }\end{array}$ & P-Value \\
\hline$\overline{\text { Brazil }}$ & $+.2499(.080)$ & .9214 & .4053 & .5104 & .6773 \\
\hline Chile & $-.1730(.229)$ & 1.3993 & .2573 & 1.3507 & .2710 \\
\hline Colombia & $-.0489(.736)$ & .2705 & .7643 & .4457 & .7216 \\
\hline Costa Rica & $+.0242(.882)$ & .1486 & .8624 & .3342 & .8007 \\
\hline Ecuador & $+.1925(.181)$ & .7747 & .4669 & 2.4146 & .0799 \\
\hline El Salvador & $+.1035(.479)$ & .1361 & .8731 & .8972 & .4508 \\
\hline Mexico & $+.3558(.010)^{*}$ & 3.7922 & $.0297^{*}$ & 2.0963 & .1144 \\
\hline Peru & $-.0271(.852)$ & .4049 & .6695 & .5694 & .6382 \\
\hline India & $+.1524(.296)$ & 3.9793 & $.0258^{*}$ & 2.4288 & .0790 \\
\hline Indonesia & $+.0157(.921)$ & .3248 & .7247 & .4042 & .7509 \\
\hline Malaysia & $-.0613(.689)$ & .0044 & .9956 & .4865 & .6938 \\
\hline Philippines & $+.1988(.162)$ & 2.0301 & .1427 & 1.3659 & .2656 \\
\hline Thailand & $-.0095(.948)$ & .2354 & .7912 & .1490 & .9298 \\
\hline South Africa & $+.4450(.001)^{* *}$ & 4.4722 & $.0167 *$ & 3.0172 & $.0398 *$ \\
\hline Australia & $+.4066(.003)^{* *}$ & 3.4246 & $.0411^{*}$ & 3.0527 & $.0385^{*}$ \\
\hline Canada & $+.3745(.007)^{* *}$ & 3.1241 & .0532 & 2.3761 & .0828 \\
\hline France & $+.3115(.028)^{*}$ & .5045 & .6072 & .1795 & .9097 \\
\hline Germany & $+.1328(.373)$ & .6956 & .5044 & 1.6771 & .1877 \\
\hline Italy & $+.1077(.508)$ & .0803 & .9230 & .5112 & .6774 \\
\hline Japan & $+.1465(.343)$ & .1895 & .8281 & .3954 & .7570 \\
\hline UK & $-.0028(.984)$ & 1.1741 & .3180 & .3293 & .8042 \\
\hline US & $+.1049(.464)$ & .2964 & .7449 & .0501 & .9850 \\
\hline
\end{tabular}


Table 2 reports the same correlations and causality tests using quarterly data. ${ }^{13}$ Note that some of the countries either do not report quarterly data, or report only substantially shorter time series. Again South Africa and Australia stand out as nations greatly influenced by El Niño, and these results appear to be quite robust. However, for the other countries the largely neutral results seen in the annual data are echoed in the quarterly data, and there is little sign that El Niño is an important factor in economic growth or business cycles for most of the economies. The quarterly correlations between the SOI and GDP growth are generally smaller and less significant than the annual ones. However, some countries, such as Costa Rica and Malaysia show statistical significance in the Granger causality tests at some horizons. Surprisingly, India shows less statistical significance, but this may be due to the paucity of quarterly observations. India, South Africa, and Australia are three countries that, because of their geographies and histories, we expect to be most influenced by the El Niño effects. However, most of the other countries appear to be little affected by El Niño. These results are unchanged when oil price inflation (or, in the case of Chile, copper price inflation) is added to the Granger causality test.

TABLE 2

Correlations of National GDP Growth with El Niño SOI and Tests of Granger Causality: SOI $\rightarrow$ Growth (Quarterly Data: 1957.1 - 2001.3, some series shorter)

(Each test includes a contemporaneous term plus a number of lags of SOI.)

\begin{tabular}{|c|c|c|c|c|c|c|c|}
\hline & $\begin{array}{c}\text { Effects on GDP } \\
\text { Growth }\end{array}$ & & & & & & \\
\hline Country C & $\begin{array}{l}\text { Correlation with } \\
\text { SOI (p-values) }\end{array}$ & $\begin{array}{c}\text { Granger } \\
\text { Causality } \\
\text { (2 lags) }\end{array}$ & P-Value & $\begin{array}{c}\text { Granger } \\
\text { Causality } \\
\text { (4 lags) }\end{array}$ & P-Value & $\begin{array}{c}\text { Granger } \\
\text { Causality } \\
\text { (6 lags) }\end{array}$ & P-Value \\
\hline Brazil & -- & -- & -- & -- & -- & -- & -- \\
\hline Chile & $-.0045(.975)$ & .4690 & .7054 & .4852 & .7851 & .4710 & .8480 \\
\hline Colombia & -- & -- & -- & -- & -- & -- & -- \\
\hline Costa Rica & -.0007 (.997) & 1.5297 & .2361 & .9326 & .4876 & 4.6439 & $.0184^{*}$ \\
\hline Ecuador & $-.3076(.057)$ & .8428 & .4809 & .8653 & .5180 & .5717 & .7700 \\
\hline El Salvador & -- & -- & -- & -- & -- & -- & -- \\
\hline Mexico & $+.0375(.731)$ & .5844 & .6270 & .3856 & .8571 & .3851 & .9079 \\
\hline Peru & $-.0595(.577)$ & .5295 & .6633 & 1.0287 & .4069 & .7637 & .6194 \\
\hline India & $+.0162(.947)$ & .1016 & .9574 & 1.6543 & .2971 & -- & -- \\
\hline Indonesia & -- & -- & -- & -- & -- & -- & -- \\
\hline Malaysia & -.0185 (.894) & .6057 & .6147 & 2.6565 & $.0364^{*}$ & 2.7199 & $.0236^{*}$ \\
\hline Philippines & $+.0222(.843)$ & .1896 & .9032 & .9755 & .4391 & .6084 & .7468 \\
\hline Thailand & $+.2267(.212)$ & .4021 & .7528 & .9966 & .4475 & 1.9320 & .1510 \\
\hline South Africa & $+.2292(.003)^{* *}$ & 2.7720 & $.0434^{*}$ & 2.5628 & $.0294^{*}$ & 2.8403 & $.0083 * *$ \\
\hline Australia & $+.1661(.031)^{*}$ & 2.9780 & $.0332 *$ & 2.7104 & $.0223^{*}$ & 1.8558 & .0809 \\
\hline Canada & $+.0526(.485)$ & .3802 & .7674 & .7009 & .6236 & .6624 & .7036 \\
\hline France & $+.2290(.010)^{* *}$ & 1.8427 & .1432 & 1.5485 & .1806 & 1.1798 & .3206 \\
\hline Germany & $+.0304(.697)$ & .0338 & .9916 & .4575 & .8073 & .5827 & .7692 \\
\hline Italy & $+.0164(.834)$ & .7066 & .5494 & .6522 & .6603 & .5696 & .7797 \\
\hline Japan & $+.0564(.455)$ & .4118 & .7447 & .6323 & .6754 & .5087 & .8270 \\
\hline UK & $-.0756(.316)$ & .7495 & .5241 & .7102 & .6166 & .9685 & .4562 \\
\hline US & $-.0104(.891)$ & 1.2711 & .2860 & 1.0124 & .4121 & .7102 & .6634 \\
\hline
\end{tabular}




\section{Correlations and causality tests between SOI and CPI inflation}

There appears to be little graphic correspondence between the SOI index and the inflation rates. Table 3 reports the correlations and tests of Granger causality between the El Niño southern oscillation index (SOI) and the annual CPI inflation for the same 22 nations. Since a negative value of the SOI index indicates the occurrence of an El Niño event, in theory, if the El Niño event is assumed to have a negative effect upon production and supply, one would expect an increase in inflation, and therefore a negative correlation between the SOI index and inflation. On the other hand, if El Niño had a negative effect upon the demand for goods or a positive effect upon supply, the El Niño effect on prices might be negative, hence producing a positive correlation between SOI and inflation.

TABLE 3

Correlations of National CPI Inflation with El Niño SOI and Tests of Granger Causality: SOI $\rightarrow$ Inflation

(Annual Data: 1950 - 2000, some series shorter)

(Each test includes a contemporaneous term plus a number of lags of SOI.)

\begin{tabular}{|c|c|c|c|c|c|}
\hline & $\begin{array}{c}\text { Effects on CPI } \\
\text { Inflation }\end{array}$ & & & & \\
\hline Country & $\begin{array}{c}\text { Correlation with } \\
\text { SOI (p-values) }\end{array}$ & $\begin{array}{c}\text { Granger } \\
\text { Causality } \\
\text { (1 lag) }\end{array}$ & P-Value & $\begin{array}{c}\text { Granger } \\
\text { Causality } \\
\text { (2 lags) }\end{array}$ & P-Value \\
\hline$\overline{\text { Brazil }}$ & $-.2554(.070)$ & .2018 & .8180 & .3708 & .7745 \\
\hline Chile & $+.3463(.013)^{*}$ & 1.7616 & .1832 & .9304 & .4343 \\
\hline Colombia & $-.2618(.063)$ & 1.2850 & .2864 & .5675 & .6394 \\
\hline Costa Rica & $-.2342(.102)$ & .5450 & .5836 & .9739 & .4141 \\
\hline Ecuador & $-.0750(.601)$ & .6097 & .5478 & .3652 & .7785 \\
\hline El Salvador & $-.1064(.458)$ & .6646 & .5193 & .6684 & .5760 \\
\hline Mexico & $-.2200(.121)$ & 3.1126 & .0540 & 2.5575 & .0676 \\
\hline Peru & $+.0131(.927)$ & .8402 & .4381 & .4938 & .6885 \\
\hline India & $-.1071(.454)$ & 1.4084 & .2549 & .9064 & .4459 \\
\hline Indonesia & $-.0629(.688)$ & .2841 & .7543 & .9406 & .4315 \\
\hline Malaysia & $+.0731(.610)$ & .6710 & .5161 & .2336 & .8725 \\
\hline Philippines & $+.1178(.410)$ & 1.3701 & .2642 & 1.9321 & .1387 \\
\hline Thailand & $+.0516(.730)$ & .0197 & .9805 & .2427 & .8660 \\
\hline South Africa & $-.2809(.046)^{*}$ & 3.8055 & $.0294^{*}$ & 1.9780 & .1311 \\
\hline Australia & $+.1022(.476)$ & 4.6308 & $.0147^{*}$ & 1.5799 & .2081 \\
\hline Canada & $-.0063(.965)$ & 3.1464 & .0522 & 2.2985 & .0906 \\
\hline France & $+.0505(.725)$ & .9156 & .4074 & .7371 & .5357 \\
\hline Germany & - .1038 (.469) & 2.5577 & .0885 & 1.1121 & .3547 \\
\hline Italy & $-.0639(.656)$ & 1.6477 & .2034 & 2.0437 & .1216 \\
\hline Japan & $+.0866(.546)$ & 3.3079 & $.0453^{*}$ & .8755 & .4611 \\
\hline UK & $+.1302(.362)$ & 5.7620 & $.0058 * *$ & 4.5259 & $.0075^{* *}$ \\
\hline$\underline{\mathrm{US}}$ & $-.0294(.838)$ & 1.0833 & .3468 & 1.3312 & .2764 \\
\hline
\end{tabular}

In this table thirteen of the twenty-two nations display a negative correlation between the SOI and the inflation rate, of which only one is significant. Interestingly, Chilean inflation is positively correlated with SOI, and therefore negatively corre- 
lated with El Niño. This makes sense because for Chile, the El Niño means heavier than normal rains and a better harvest, and is therefore associated with "years of abundance." Thus in the case of Chile we see a positive supply shock for agricultural goods. However this relationship disappears in the Granger causality tests. For South Africa the El Niño means drought, and the correlation is correspondingly negative and significant, as is the Granger causality test with a contemporaneous term and one lag. Surprisingly, the only other statistically significant results are between SOI and the inflation rates of three of the developed countries. This is a plausible finding for Australia because it is directly subject to severe drought during an El Niño event. For the UK, this positive correlation could be due to the decreased price of heating oil during an El Niño event. The significant Granger causal effect on Japanese inflation appears to be weak and does not reappear in the quarterly and monthly data.

TABLE 4

Correlations of National CPI Inflation with El Niño SOI and Tests of Granger Causality: SOI $\rightarrow$ Inflation

(Quarterly Data: 1957.1 - 2001.3, some series shorter)

(Each test includes a contemporaneous term plus a number of lags of SOI.)

\begin{tabular}{|c|c|c|c|c|c|c|c|}
\hline & $\begin{array}{c}\text { Effects on CPI } \\
\text { Inflation }\end{array}$ & & & & & & \\
\hline Country C & $\begin{array}{l}\text { Correlation with } \\
\text { SOI (p-values) }\end{array}$ & $\begin{array}{c}\text { Granger } \\
\text { Causality } \\
\text { (2 lags) }\end{array}$ & P-Value & $\begin{array}{c}\text { Granger } \\
\text { Causality } \\
\text { (4 lags) }\end{array}$ & P-Value & $\begin{array}{c}\text { Granger } \\
\text { Causality } \\
\text { (6 lags) }\end{array}$ & P-Value \\
\hline$\overline{\text { Brazil }}$ & $-.1510(.165)$ & 1.7935 & .1553 & .9750 & .4390 & .8560 & .5458 \\
\hline Chile & $+.2485(.001)^{* *}$ & .4530 & .7155 & .4402 & .8199 & .4207 & .8884 \\
\hline Colombia & $-.1893(.011)^{*}$ & 1.5945 & .1926 & 1.8472 & .1064 & 2.1557 & $.0409 *$ \\
\hline Costa Rica & $-.1707(.026)^{*}$ & .7698 & .5125 & .6671 & .6490 & .6536 & .7109 \\
\hline Ecuador & $+.0284(.706)$ & 1.3691 & .2540 & 1.1555 & .3334 & .6969 & .6746 \\
\hline El Salvador & c $\quad-.0703(.351)$ & .1250 & .9452 & 1.3101 & .2622 & 1.4293 & .1971 \\
\hline Mexico & $-.2592(.000)^{* *}$ & 1.8450 & .1409 & 1.8467 & .1065 & 1.2089 & .3009 \\
\hline Peru & $+.0538(.476)$ & 1.4068 & .2426 & 1.2893 & .2710 & 1.4553 & .1871 \\
\hline India & $-.0536(.477)$ & 1.9116 & .1296 & 2.1333 & .0640 & 1.3774 & .2184 \\
\hline Indonesia & $+.0549(.529)$ & 1.3161 & .2721 & .9588 & .4460 & 1.1094 & .3620 \\
\hline Malaysia & $+.0818(.278)$ & .8309 & .4786 & .9278 & .4645 & .9937 & .4379 \\
\hline Philippines & $+.1994(.008) * *$ & 2.0838 & .1042 & 2.8455 & $.0172 *$ & 2.4244 & $.0219 *$ \\
\hline Thailand & $+.0472(.571)$ & .2959 & .8283 & .2956 & .9147 & .4616 & .8606 \\
\hline South Africa & $\mathrm{a}-.1065(.161)$ & .9094 & .4378 & .9910 & .4251 & 1.3494 & .2308 \\
\hline Australia & $+.1649(.028)^{*}$ & 1.7595 & .1568 & 1.6448 & .1510 & 1.4138 & .2032 \\
\hline Canada & $+.1053(.162)$ & .7256 & .5380 & 1.0676 & .3803 & .8328 & .5615 \\
\hline France & $+.0477(.527)$ & .2469 & .8635 & .8808 & .4954 & 1.0017 & .4322 \\
\hline Germany & $+.0333(.659)$ & .8069 & .4916 & 1.3142 & .2605 & .8106 & .5797 \\
\hline Italy & $+.0126(.867)$ & .8986 & .4432 & .8928 & .4874 & .6402 & .7221 \\
\hline Japan & $+.2464(.001)^{* *}$ & 1.7419 & .1603 & .9516 & .4493 & .7773 & .6072 \\
\hline UK & $+.1967(.009)^{* *}$ & .6011 & .6151 & 1.5475 & .1779 & 1.3079 & .2499 \\
\hline US & $+.1311(.081)$ & .7845 & .5041 & .7373 & .5965 & .4907 & .8403 \\
\hline
\end{tabular}

The same pattern does not appear in the quarterly data in Table 4 nor in the monthly data. ${ }^{14}$ For the quarterly data in Table 4, most of the correlations between the SOI and the CPI inflation rates are smaller than those in the annual data, while 
they are statistically more significant due to the increased number of observations. However, the Granger causality tests show much less statistical significance, especially for the developed nations. This may be partly due to the shorter period of the quarterly data (1957.1 - 2001.3) relative to the annual data $(1950-2001)$. On the other hand, we see an increased statistical significance for the Philippines inflation rate at the four and six quarter horizons.

As for the monthly data results, most of the correlations are even smaller. The smaller correlation coefficients are likely due to the fact that the monthly changes in inflation have little to do with the El Niño effects and are probably just introducing more noise into the analysis. In the Granger causality tests, only the Philippine inflation rate at the twelve-month horizon is statistically significant. Overall, what is most striking about these results is the lack of statistical significance between the El Niño SOI and the CPI inflation rates of the countries examined.

\section{Correlations and causality tests between SOI and commodity price inflation}

Figure 3 displays the graphs contrasting the SOI index and the commodity price inflation rates for a selected set of commodities. The graphs show only a modest degree of correspondence. Table 5 reports the correlations and the tests of Granger causality between the SOI index and the annual commodity price inflation rates for fifteen commodities. In general, again, if El Niño has a negative impact on production, one would expect to observe negative correlations between the SOI and the commodity inflation rates. However, in certain cases, an El Niño event may have salutary effects on the production of certain commodities in certain regions. Negative correlations are found for seven of the fifteen commodities and positive correlations for eight of the fifteen commodities. However, only maize and sorghum display statistically significant correlations, and these are both positive. One might note that much of the world maize crop comes from the US Midwest, which experiences higher temperatures during an El Niño event and higher production yields, as noted by Handler and Handler [1983].

In the Granger causality tests with a contemporaneous term and one annual lag, there is evidence of statistically significant Granger causality between the SOI and commodity price inflation in maize and sorghum. In Granger causality tests of a contemporaneous term and two annual lags, there is significant evidence of Granger causality between SOI and price inflation in maize, sorghum, and soybeans. Rice price inflation is nearly significant at one and two annual lags.

Table 6 report the same correlations and Granger causality tests using quarterly data. Using higher frequency data gives the advantage of having a greater number of observations. It also gives a higher resolution view of the effects of El Niño upon the economy and may capture more of the seasonal effects. In Table 6, which uses quarterly commodity price inflation, we find that SOI has a statistically significant effect upon maize price inflation at the two quarter, four quarter, and almost at a six quarter lag length, and it consequently appears that maize price inflation is affected by the El Niño effects. Coconut price inflation appears to be Granger caused by El Niño at four and six quarter lags, while the price inflation of palm oil is significant at six lags and almost significant at two and four lags. Rice price inflation is significant at two lags. 
FIGURE 3

Commodity Price Inflation and the SOI Index
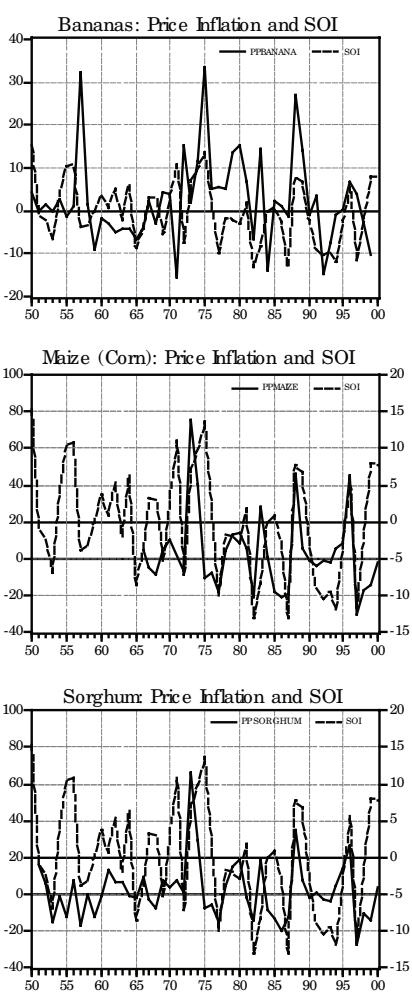
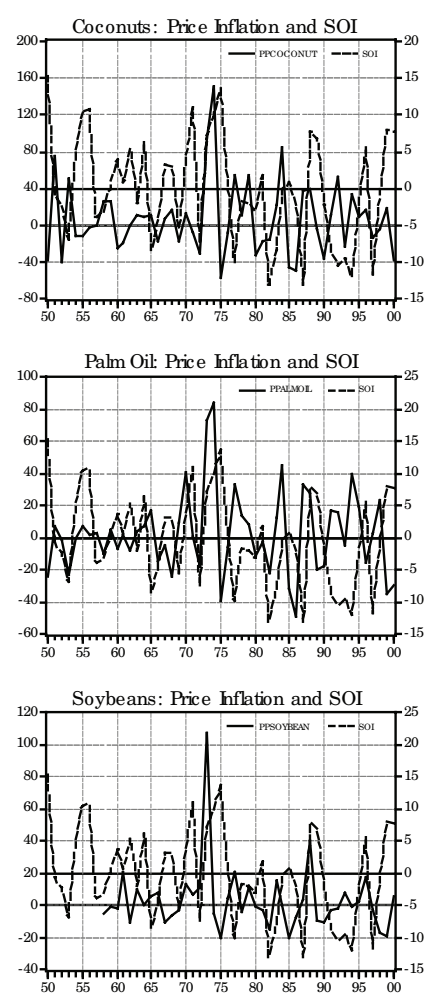
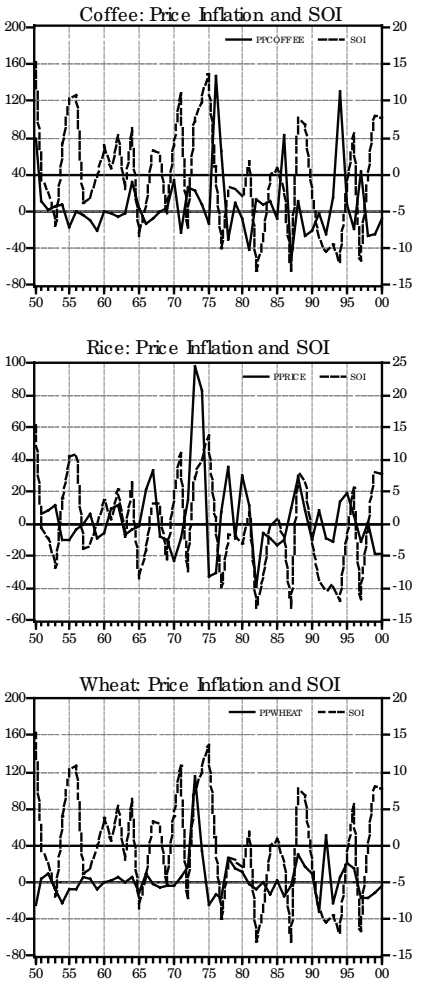

Analyzing the same statistics using monthly data (1957.01-2001.10), all the statistics are insignificant, in spite of the greater number of degrees of freedom. ${ }^{15}$ This may be because the El Niño effects take time for the effects to be realized and the results of El Niño might not be felt until the end of the growing season. It may also be that because of the volatility of monthly weather fluctuations, the use of monthly data may simply be adding more noise to the regressions. Overall the most robust findings for commodity prices appears to be that El Niño has a significant effect on the commodity price inflation for maize and a sometimes significant effect on coconuts, palm oil, rice, and sorghum. The prices of other commodities do not appear to be significantly affected by El Niño events.

\section{CONCLUSION}

The major question studied here is the effect of the El Niño-Southern Oscillation (ENSO) phenomenon upon business cycles - that is, what are the effects of El Niño upon economic growth, consumers' prices and commodity prices in the nations most exposed to the El Niño? This is an important question because nations strongly affected by El Niño may desire to engage in counter-cyclical macroeconomic policy in order to soften the effects of the phenomenon. 


\section{TABLE 5}

Correlations of Commodity Price Inflation with El Niño SOI and

Tests of Granger Causality: SOI $\rightarrow$ Commodity Inflation

(Annual Data: 1950 - 2000, some series shorter)

(Each test includes a contemporaneous term plus a number of lags of SOI.)

\begin{tabular}{lccccc}
\hline \multicolumn{2}{c}{$\begin{array}{c}\text { Effects on } \\
\text { Commodity Inflation }\end{array}$} & & & & \\
\hline Commodity & $\begin{array}{c}\text { Correlation with } \\
\text { SOI (p-values) }\end{array}$ & $\begin{array}{c}\text { Granger } \\
\text { Causality } \\
(\mathbf{1 ~ l a g )}\end{array}$ & P-Value & $\begin{array}{c}\text { Granger } \\
\text { Causality } \\
\text { (2 lags) }\end{array}$ & P-Value \\
\hline Bananas & $+.1591(.270)$ & 1.0914 & .3443 & 1.3934 & .2577 \\
Cacao & $-.1372(.337)$ & .6074 & .5490 & 2.4201 & .0787 \\
Coconut & $-.0584(.684)$ & 1.0341 & .3637 & 1.3184 & .2808 \\
Coffee & $-.1147(.423)$ & .6776 & .5127 & 1.0649 & .3737 \\
Cotton & $-.0123(.944)$ & .0841 & .9196 & .6782 & .5730 \\
Maize & $+.3998(.017) *$ & 8.5005 & $.0012^{* * *}$ & 7.3563 & $.0009^{* *}$ \\
Palm Oil & $-.1109(.439)$ & 2.3723 & .1043 & .2343 & .8720 \\
Pepper & $-.1431(.322)$ & 1.1266 & .3330 & 1.2381 & .3076 \\
Rice & $+.1159(.423)$ & 2.5732 & .0875 & 2.5749 & .0666 \\
Rubber & $+.2492(.078)$ & 2.1266 & .1306 & .9891 & .4067 \\
Sorghum & $+.3263(.021) *$ & 7.1668 & $.0020^{* *}$ & 5.8364 & $.0020^{* *}$ \\
Soybeans & $+.0914(.560)$ & 1.4732 & .2420 & 3.3423 & $.0301^{*}$ \\
Sugar & $+.2241(.114)$ & .9308 & .4014 & .5009 & .6836 \\
Tea & $-.1206(.430)$ & .2115 & .8102 & .4381 & .7271 \\
Wheat & $+.1110(.438)$ & 1.5327 & .2266 & 1.8126 & .1588 \\
\hline
\end{tabular}

\section{TABLE 6}

\section{Correlations of Commodity Price Inflation with El Niño SOI and} Tests of Granger Causality: SOI $\rightarrow$ Commodity Inflation

(Quarterly Data: 1957:1 - 2001.3, some series shorter)

(Each test includes a contemporaneous term plus a number of lags of SOI.)

\begin{tabular}{|c|c|c|c|c|c|c|c|}
\hline \multicolumn{8}{|c|}{$\begin{array}{c}\text { Effects on } \\
\text { Commodity Inflation }\end{array}$} \\
\hline $\begin{array}{l}\text { Com- } \\
\text { modity }\end{array}$ & $\begin{array}{l}\text { Correlation with } \\
\text { SOI (p-values) }\end{array}$ & $\begin{array}{c}\text { Granger } \\
\text { Causality } \\
\text { (2 lags) }\end{array}$ & P-Value & $\begin{array}{c}\text { Granger } \\
\text { Causality } \\
\text { (4 lags) }\end{array}$ & P-Value & $\begin{array}{c}\text { Granger } \\
\text { Causality } \\
\text { (6 lags) }\end{array}$ & P-Value \\
\hline Bananas & $+.0225(.770)$ & 1.4738 & .2236 & .8033 & .5489 & 1.2619 & .2730 \\
\hline Cacao & - .0778 (.303) & 1.3016 & .2756 & 1.1642 & .3291 & 1.3940 & .2114 \\
\hline Coconut & $+.0347(.679)$ & 1.8153 & .1473 & 2.7237 & $.0224^{*}$ & 2.3942 & $.0248^{*}$ \\
\hline Coffee & $-.0700(.353)$ & .9854 & .4011 & .6583 & .6556 & .5937 & .7604 \\
\hline Cotton & $+.0658(.464)$ & .8462 & .4713 & .6077 & .6941 & 1.1537 & .3358 \\
\hline Maize (G) & $+.0345(.648)$ & 4.2196 & $.0066^{* *}$ & 2.8063 & $.0185^{*}$ & 1.9493 & .0653 \\
\hline Palm Oil & $-.0685(.364)$ & 2.5012 & .0612 & 2.1445 & .0627 & 2.3802 & $.0243^{*}$ \\
\hline Pepper & $-.1770(.152)$ & .9835 & .4068 & .9393 & .4633 & 1.1165 & .3688 \\
\hline Rice & $-.0040(.957)$ & 3.0052 & $.0319 *$ & 1.8753 & .1013 & 1.3769 & .2186 \\
\hline Rubber & $-.0587(.436)$ & 2.2704 & .0822 & 1.3632 & .2408 & 1.3417 & .2341 \\
\hline Sorghum & $+.0264(.759)$ & 2.4902 & .0632 & 1.8184 & .1140 & .9615 & .4626 \\
\hline Soybeans & $-.0477(.527)$ & 1.8041 & .1483 & 1.3329 & .2528 & 1.0950 & .3690 \\
\hline Sugar & -- & -- & -- & -- & -- & -- & -- \\
\hline Tea & $-.1466(.121)$ & 1.2496 & .2956 & .9318 & .4638 & 1.1830 & .3202 \\
\hline Wheat & $+.0178(.818)$ & 2.4121 & .0687 & 1.7615 & .1239 & .8642 & .5364 \\
\hline
\end{tabular}

The global effects of the El Niño-Southern Oscillation phenomenon can actually be quite profound, and can affect the entire globe and many national economies on 
an episodic basis. Some commentators, such as Davis [2001] and Caviedes [2001], say that the effects of El Niño are decisive in history, and they cite tragic famines and ENSO driven weather anomalies as critical historical events. However, those disasters occurred in a world with less free trade and less international relief, when regions were therefore more vulnerable to local conditions.

Overall we do not find much evidence of a continuing and recurring effect of $\mathrm{El}$ Niño upon the growth rate of the national economies. The findings are reminiscent of the historical rejection of Jevons' sunspot theory of business cycles. We do not find the El Niño-Southern Oscillation to be a driving force behind national business cycles. The main exceptions are South Africa and Australia, and perhaps India and Malaysia, which appear to be affected adversely by El Niño events. In addition, we find the effects of El Niño upon inflation rates to be insignificant for most of the countries studied, except for South Africa, Australia, and the UK, and perhaps the Philippines. Similarly, while El Niño appears to have a significant effect upon the price of maize and perhaps modestly upon the prices of sorghum, rice, coconuts, and palm oil, it appears to have had little effect upon the prices of most of the commodities studied.

Initially we believed that El Niño would have significant effects upon the GDP growth and business cycles of the many of the countries studied - particularly upon the smaller and the less developed countries. It was felt that small countries with little industrial diversification and countries located in the immediate region of the El Niño phenomenon (such as Peru and Chile) would be particularly vulnerable. However, an examination of graphs, correlations, and Granger causality tests reveal that the effects of El Niño upon national economies are generally statistically insignificant. It was therefore unnecessary to analyze the effects of country size, location, industrial diversification, and level of development to gauge the vulnerability of an economy to El Niño effects.

These results contrast markedly with the results of Brunner [2002] who found significant evidence of an impact of the El Nino SOI index upon the aggregate growth rates of the G-7 nations. Why are the results here different? We note three reasons. First, Brunner investigates only the most developed countries, and we study both developed and developing countries. Second, Brunner's paper reports results for an aggregate of the G-7 countries, whereas the present research analyzes the results for individual countries. We would argue that the relationship between the growth of individual countries and El Niño (SOI) is the more relevant question. Third, Brunner analyzes the relationship between the G-7 aggregate growth and the SOI index using a vector autoregression-impulse response-variance decomposition technique and does not report the direct Granger causality test results for the effects on GDP growth and inflation rates. ${ }^{16}$

Why are our results so weak? First, it may be that the effects of El Niño episodes are actually small relative to the size of the economies. This is certainly true in the case of the US, as shown by Changnon [1999]. For most of the countries, the sizes of the agriculture and fishery sectors of the economy are small relative to the rest of the economy. This fact would tend to make the countries less vulnerable to climatic fluctuations. 
Second, it is important to note that some of the effects of El Niño are positive, and these positive effects will tend to offset some of the negative effects of El Niño. This is particularly true for economies with a variety of regions and a diversity of crops and industries. Due to the cancellation of positive and negative effects, the aggregate net effect may be negligible. This cancellation effect may be important even for LDC countries that are directly subject to the El Niño phenomenon such as Peru and Chile.

Third, the El Niño phenomenon is complex. The geographical distribution patterns of El Niño effects vary from episode to episode, thus the effects are not always the same. It is this characteristic of El Niño that the unidimensional SOI index fails to capture. Therefore, holding the SOI index constant, the El Niño effects on a national economy may for some episodes be large and for other episodes small.

Fourth, El Niño often changes the probabilities of storms and hurricanes hitting a given country. However, a change in probabilities does not guarantee that these storms will occur, nor can we directly observe the probabilities. All of these points will tend to weaken the correlation between the strength of the El Niño and economic consequences.

Finally, the current analysis does not take into consideration other factors behind the economic growth of these countries. A more detailed analysis of each country would involve the specification of a detailed growth model for each national economy, in an effort to control for the effects of third factors. But this is beyond the scope of the current paper and will be addressed in future research. However, based upon the results of Norrbin and Schlangenhauf [1988], it is our judgment that the results will not change.

Nonetheless, for certain localities within a country, the El Niño may have an important effect upon economic well-being. With the increasing knowledge of the existence of and the ability to measure and forecast El Niños, some of the negative ENSO effects might be ameliorated through the use of appropriate fishing and agricultural policy responses to an El Niño or La Niña event, including improved fishing strategies, irrigation, water storage, construction, and forest fire preparation. As for policy implications, it is clear from the literature on El Niño that many regions and industries are affected by El Niño and can benefit from the accurate forecasting of El Niño events. These regions and industries may then have the time to take countermeasures to ameliorate the effects of an El Niño event before it occurs. However, macroeconomic policy adjustments are not as necessary, because the El Niño phenomenon results in more of a redistribution of positive and negative effects, rather than an overall, unambiguous negative or positive shock. Therefore, it appears from the present research that it is not necessary for most national governments to make such adjustments to national fiscal and monetary policy to soften the effects of the ENSO oscillation. Rather, governments should be more concerned with microeconomic policy for particular regions or industries.

In an extension of this research, there is a need for more in depth study of the economic effects of El Niño on specific industries, commodities and localities. Another area for future research might be the study of the historical relationship between El Niño and business cycles. 


\section{DATA APPENDIX}

SOI Data: The Australian Bureau of Meteorology.

Website: "www.bom.gov.au/climate/current/soihtm1.stml"

IMF International Financial Statistics

(IFS Yearbooks, various years)

IMF International Statistics (IFS, CD-ROM, June 1997)

IMF International Financial Statistics (IFS, CD-ROM, 3/99)

IMF International Financial Statistics (IFS, CD-ROM, 12/01)

The real GDP statistics for all countries come from IMF IFS series 99 bp and 99 br. The inflation statistics are calculated from the CPI series from IMF IFS series 64 . The commodity prices come from IMF IFS series 74 and 76 for various countries.

The early annual Latin American real GDP statistics come from the Statistical Abstract of Latin America (SALA), Vol. 32, 1996, James W. Wilkie, Editor, Los Angeles: UCLA Latin American Center Publications, The Regents of the University of California. GDP series, 1950-90, (Millions US 1980 \$), Table 3423, p. 1093-1094.

\section{NOTES}

The authors would like to thank Richard A. Miller for his suggestion that led to this paper, and Allan Brunner, Chris Colburn, Robert Dekle, Chris Drake, Richard Grossman, Takako Hanashiro, Terri Mathews, Anil Nair, Mohammad Najand, Charlie Turner, and Denny Kirwan for their helpful comments. In addition, the authors want to thank the editors and three anonymous referees for their valuable comments and suggestions.

1. Strictly speaking, El Niño refers to the ocean temperature effects of the El Niño-Southern Oscillation or ENSO phenomenon. However, for brevity, we will use the terms El Niño or ENSO interchangeably to represent the El Niño-Southern Oscillation phenomenon.

2. Davis (2001) estimates that the famine death toll over the 26 year period was between 30 and 60 million people. Similar figures are quoted by Grove and Chappell (2000).

3. The connection between El Niño and tornadoes has still not been unequivocally demonstrated.

4. Using monthly industrial production indexes (IP) as a substitute for GDP data would not make sense because industrial production explicitly excludes agriculture and fishing.

5. The Southern Oscillation Index (SOI) is an index based on monthly deviations from the monthly mean in the air pressure differential between Tahiti and Darwin, Australia:

$$
S O I=\frac{10 \cdot(\text { Pdiff }- \text { Pdiffav })}{S D(\text { Pdiff })}
$$

where MSLP $=$ Mean Sea Level Pressure for the month

Pdiff $=($ Tahiti MSLP for the month $)-($ Darwin MSLP for the month $)$

Pdiffav = Long term average Pdiff for the month

$\mathrm{SD}$ (Pdiff) = Long term standard deviation of Pdiff for the month.

6. For the longer periods we used averages. Alternatively we could have used the values for individual months, but that method throws away information and relies on mere chance that the observation for the selected month is representative of the entire period. It was therefore judged that averages would be more representative of the period and would smooth the fluctuations due to the vagaries of the weather. 
7. E-Views 4.0 and 5.0 were used for all estimations, see Quantitative Micro Software LLC (2004).

8. These Augmented Dickey-Fuller (ADF) test results are available from the authors upon request.

9. See Engle and Granger (1991), p. 84, and Charemza and Deadman (1992), p. 147, regarding this issue.

10. The standard test of Granger causality uses only lags of the explanatory variable. The standard tests give results very similar to the results reported here, but with slightly less statistical significance.

11. These results are available from the authors upon request.

12. It should be pointed out that a priori there is no reason to assume that an El Niño event will have a negative effect on a nation or region. Indeed, some nations, like the US, are net beneficiaries of El Niño events and are hurt by the other side of the cycle, the La Niña.

13. Some of the countries have shorter data series, and sufficiently long quarterly data series were unavailable for Brazil, Colombia, El Salvador, and Indonesia.

14. The monthly data analysis is available from the authors upon request.

15. These statistics are available from the authors upon request.

16. It should be pointed out that Brunner does report Granger causality test results for commodity prices.

\section{REFERENCES}

Adams, R. M., Bryant, K. J., McCarl, B. A., Legler, D., O’Brien, J., Solow, A., and Weiher, R. Value of Improved Long-Range Weather Information. Contemporary Economic Policy, 8, 1995, 10-19.

Bidegain, M. and Krecl, P. Associations between Surface Temperature Anomalies over Southeastern South America (Uruguay) and El Niño/Southern Oscillation (ENSO). Paper presented at the Global Change Symposium, $79^{\text {th }}$ Annual Meeting of the American Meteorological Society, January 10-15, 1999, Dallas, Texas.

Bove, M. C. Impacts of ENSO On United States Tornadic Activity. Working paper, Center for Ocean-Atmospheric Prediction Studies (COAPS), Florida State University, Tallahassee, FL, April 9, 1999. Paper under submission to the Journal of Geophysical Research - Atmospheres.

Bove, M. C., Elsner, J. B., Landsea, C., Niu, X., and O’Brien, J. Effects of El Niño on U.S. Landfalling Hurricanes. Bulletin of the American Meteorological Society, 79, 1998, 2477-2482.

Brunner, A. D. El Niño and World Primary Commodity Prices: Warm Water or Hot Air? Review of Economics and Statistics, 84, 1, 2002, 176-183.

Caviedes, C. N. El Niño in History: Storming Through the Ages. Gainesville, FL: University Press of Florida, 2001.

Changnon, S. A. Impacts of 1997-98 El Niño-Generated Weather in the United States. Bulletin of the American Meteorological Society, 80, 9, 1819-1827, September 1999.

Charemza, W. W. and Deadman, D. F. New Directions in Econometric Practice. Hants, England: Edward Elgar, 1992.

Costello, C. J., Adams, R. M., and Polasky, S. The Value of El Niño Forecasts in the Management of Salmon: A Stochastic Dynamic Assessment. American Journal of Agricultural Economics, 80, 4, 1998, 765-778.

Dalton, M. G. El Niño, Expectations, and Fishing Effort in Monterey Bay, California. Journal of Environmental Economics and Management, 42, 2001, 336 - 359.

Davis, M. Late Victorian Holocausts: El Niño Famines and the Making of the Third World. London, UK: Verso, 2001.

Engle, R. F. and Granger, C. W. J. Long-Run Economic Relationships: Readings in Cointegration. Oxford, Oxford University Press, 1991.

Gray, W. M. Atlantic Seasonal Hurricane Frequency. Part I: El Niño and 30 mb Quasi-Biennial Oscillation Influences. Monthly Weather Review, 1984.

Grimm, A. M., Ferraz, S. E. T., and Gomes, J. Precipitation Anomalies in Southern Brazil Associated with El Niño and La Niña Events. Journal of Climate, 11, 11, 1998, 2863.

Grove, R. H. and Chappell, J., editors. El Niño - History and Crisis. Cambridge, UK: The White Horse Press, 2000.

Handler, P. and Handler, E. Climatic Anomalies in the Tropical Pacific Ocean and Corn Yields in the United States. Science, Vol. 220, 10, June 1983, 1155-1156. 
Jevons, W. S. Commercial Crises and Sunspots, in Investigations in Currencies and Finance, edited by H. S. Foxwell. London: McMillan and Company, Ltd, 1884.

Jordan, R. Impact of ENSO Events on the Southeastern Pacific Region with Special Reference to the Interaction of Fishing and Climate Variability, in Teleconnections Linking Worldwide Climate Anomalies, edited by M. H. Glantz, R. W. Katz, and N. Nicholls. Cambridge: Cambridge University Press, 1991, 401-430.

Keppenne, C. L. An ENSO Signal in Soybean Futures Prices. Journal of Climate, 8, 1995, 1685-1689.

Knowles, J. B. and Pielke, R. A. The Southern Oscillation and its Effects on Tornadic Acitivity in the United States. Unpublished manuscript, 1993.

Kreitner, R. E., Smith, S. R.; and O'Brien, J. J. Front Range Severe Flash Flooding and El Niño. Working paper, Center for Ocean-Atmospheric Prediction Studies (COAPS), Florida State University, Tallahassee, FL, January 7, 2000.

Legler, D. M., Bryant, K. J., and O’Brien, J. J. Impact of ENSO-Related Climate Anomalies on Crop Yields in the US. Working Paper, Florida State University, Center for Ocean Atmospheric Prediction Studies, March 1998.

Letson, D. and McCullough, B. D. ENSO and Soybean Prices: Correlation without Causality. Journal of Agricultural and Applied Economics, 33, 3, 2001, 513 - 521.

Norrbin, S. C. and Schlagenhauf, D. E. An Inquiry into the Sources of Macroeconomic Fluctuations. Journal of Monetary Economics, 22, 1988, 43-70.

Quantitative Micro Software, LLC. Eviews 5.0. Irvine, California: Quantitative Micro Software, LLC, 2004.

Richards, T.S. and O'Brien, J. J. The Effect of El Niño on U.S. Landfalling Hurricanes. Bulletin of the American Meterological Society, 77, 1996, 773-74.

Roll, R. Orange Juice and Weather. American Economic Review, 74, 5, 1984, 861-880.

Ropelewski, C. F. and Halpert, M. S. Quantifying Southern Oscillation-Precipitation Relationships. Journal of Climate, 9, 1996, 1043-1059.

. Precipitation Patterns Associated with High Index Phase of the Southern Oscillation. Journal of Climate, 2, 1989, 268-284.

- Global and Regional Scale Precipitation Patterns Associated with the El Niño/Southern Oscillation. Monthly Weather Review, 115, 1987, 1606-1626. 